\title{
Assessment of Changes in Microbial Communities in Different Operational Units from a Wastewater Treatment Plant
}

\author{
Nilgün Poyraz, Mehmet Burcin Mutlu* \\ Department of Biology, Faculty of Science, Anadolu University \\ TR 26470 Eskisehir, Turkey
}

Received: 22 November 2016

Accepted: 8 February 2017

\begin{abstract}
Microbial communities in wastewater play an important role in treatment, and especially microbial community composition and changes have great influence on biological treatment. In these cases, monitoring and evaluating the changes with practical methods becomes important. Ecoplates may be an effective and quick method for assessing microbial activity. Therefore, we observed, with Ecoplates, the microbial community function of different operational units from wastewater treatment plants.

Wastewater and sludge samples used in the study were taken from different units of a sewage treatment plant located in the Eskisehir in two different time intervals. Changes in wastewater samples' metabolic diversity and microbial activity were evaluated. High similarity rates were obtained from samples, as indicated by the diversity indices and average well color development (AWCD) values. A return activated sludge pump and anaerobic digestion unit were highly active in the community. Low substrate usage rates were observed in the secondary classifier unit and the lowest used substrate was 2-hydroxybutyric acid from the carboxylic acid group. The most actively used substrates were from the carbohydrate group substrates. These results refer to the degradation capacity. In addition, results showed that sampling intervals and operational conditions caused changes in the functional diversity of communities. This study allowed us to gather general information about microbial community structures in different operational units of wastewater treatment systems. The results obtained from the study showed that this method is useful for monitoring the treatment process, bacterial changes, and operational parameters.
\end{abstract}

Keywords: wastewater, ecoplate, microbial community, AWCD, diversity indices, carbon utilization

\section{Introduction}

As a result of climate change and the estimated scarcity of clean water resources, it is necessary to enhance the

*e-mail: mbmutlu@anadolu.edu.tr monitoring of water quality in Europe and other parts of the world. Wastewater treatment is crucial for the reduction of health risks and adverse impacts on the environment caused by the discharge of untreated wastewater [1-2]. Typically, wastewater is treated in wastewater treatment plants in the activated sludge process. Fundamentally, the process is identical as it was a century ago. However, 
the technological development enabled the removal of phosphorus and nitrogen in addition to organic material. This is carried out by exploiting the features of various microorganisms. Nevertheless, it is imperative to improve the process further because of increased volumes of wastewater and because accepted effluent concentrations of nutrients are becoming lower. Accordingly, it is critical to comprehend the factors behind the composition and dynamics of the microbial communities located in the wastewater treatment plants. Groups of bacteria have been identified and described for several processes in biological wastewater treatment, such as unwanted foaming [3], phosphorus removal [4], and nitrogen [5].

Furthermore, it is necessary to know the requirements of phosphorus accumulation and nitrifying bacteria and the growth rate to appropriately configure the activated sludge process. Nevertheless, there are numerous unanswered questions related to the communal level of bacteria in an activated sludge at a community level. The method of community formation is unknown, as well as the dynamics of the communities and the optimal community composition. Finding answers to these questions is a requirement for improving the treatment of wastewater [6-9].

The applied ecological research uses The Biolog system to identify microbes and to discover modifications primarily in soil microbial communities [10-17]. The objective of the study was to use a community-level physiological profiling (CLPP) methodology as an assay for describing the wastewater microorganisms' metabolic diversity. Our study used metabolic fingerprints collected from chosen samples to analyze functional diversity indicated by the carbon substrate shifts. The results enabled us to collect general information about the structure of microbial communities in several operational units of treatment systems for wastewater. The method proved efficient for monitoring operational parameters, bacterial changes, and treatment processes.

\section{Materials and Methods}

\section{Sample Collection}

Wastewater and sludge samples used in the study were taken from different units of a sewage treatment plant, located in the Eskisehir, in two seasonally different time intervals. This wastewater treatment plant is a biological treatment plant consisting of a conventionally activated sludge process.

Sampling units were the fat/sand removal unit (FSRU), primary clarifiers unit (PCU), activated sludge unit (ASU), secondary clarifiers unit (SCU), return-activated sludge pump (RASP), and anaerobic digester unit (ADU). In total, 12 samples were taken in winter (January) and spring (April). All samples were obtained manually, and 3,000-5,000 $\mathrm{ml}$ samples were taken and placed in labeled plastic bottles from each sampling point. Samples in plastic carriers were quickly transported to the laboratory and the experimental procedures were carried out immediately.

\section{Physico-Chemical Analysis}

The $\mathrm{pH}$ of samples was measured with a $\mathrm{pH}$ meter (Mettler Toledo) and chemistry of samples were determined with a Perkin Elmer Optima 4300 DV optical emission spectrophotometer in the Anadolu University Medicinal Plants, Drugs, and Scientific Research Center.

For inductively coupled plasma (ICP) analysis of samples at the different dilution rates $(10-, 100-$, and 1,000-fold dilutions) were prepared and analyzed. Data analysis was carried out by SPSS (version 16) software. To compare the ICP data in both groups (January and April), we used Student's T-test. The significance level applied for test analyses was 0.05 .

\section{Enumeration of Mesophilic Bacteria}

The number of mesophilic bacteria was determined by counting bacterial colonies on a plate count agar (PCA) media. Serial dilutions of samples on solid agar medium were used. $1 \mathrm{ml}$ samples were placed in glass tubes containing $9 \mathrm{ml}$ of $0.85 \%$ sterile $\mathrm{NaCl}$. Serial tenfold dilutions of samples were inoculated to solid media by the spread plate technique. Plates were incubated for 24 hours at $37^{\circ} \mathrm{C}$ and enumerated [18].

\section{Community-Level Substrate Utilization Profile}

To determine the community physiological profile we used a 96 well Biolog EcoPlate (Biolog Inc., Hayward, California). Ecoplate contains 31 carbon sources and one blank in three replicate sets. These carbon sources are included in various groups (Table 1) [19-20]. Brief centrifuging was applied to viscous and particulate samples. Then, 150 microliters of each sample was transferred to each Biolog Ecoplate well and 150 microliters of water was added to the control well. Absorbance at $590 \mathrm{~nm}$ was measured on a Biolog Microstation at 24-hour intervals for up to four days. Data was recorded by using Microlog Data Collection Software (Biolog, Inc.) and, with this data, carbon utilization profiles of samples were verified.

\section{Determining Functional Diversity}

Data recorded for 96 hours was used in the calculation of various diversity indices. For every 24 hours, substrate richness or catabolic richness (S) were determined. S value was calculated as the total number of oxidized substrate (C). This number was the total number of wells in the absorbance value over 0.25 .

The Shannon-Wiener functional diversity index $(\mathrm{H})$ was calculated by the following formula (Eq. 1) [19]:

$$
H=-\sum_{n=1}^{31}(\text { pi(Inpi) })
$$


Table 1. Biolog EcoPlates carbon source groups.

\begin{tabular}{|c|c|c|c|c|c|}
\hline Well & C-source & Group & Well & C-source & Group \\
\hline A1 & Water & - & A3 & D-Galactonic acid- $\gamma$-lactone & Carboxylic and Acetic acids \\
\hline B1 & Pyruvic acid methyl ester & Carbohydrates & B3 & D-Galactyronic acid & Carboxylic and Acetic acids \\
\hline C1 & Tween 40 & Polymers & C3 & 2-Hydroxybenzoic acid & Carboxylic and Acetic acids \\
\hline D1 & Tween 80 & Polymers & D3 & 4-Hydroxybenzoic acid & Carboxylic and Acetic acids \\
\hline E1 & $\alpha$ - Cyclodextrin & Polymers & E3 & $\gamma$-Hydroxybutyric acid & Carboxylic and Acetic acids \\
\hline F1 & Glycogen & Polymers & F3 & Itactonic acid & Carboxylic and Acetic acids \\
\hline G1 & D-Cellobiose & Carbohydrates & G3 & $\alpha$-Ketobutyric acid & Carboxylic and Acetic acids \\
\hline H1 & $\alpha$-D-Lactose & Carbohydrates & H3 & D-Malic acid & Carboxylic and Acetic acids \\
\hline A2 & $\beta$-Methyl-D-glucoside & Carbohydrates & A4 & L-Arginine & Amino acids \\
\hline B2 & D-Xylose & Carbohydrates & B4 & L-Asparagine & Amino acids \\
\hline C2 & i-Erythritol & Carbohydrates & $\mathbf{C 4}$ & L-Phenyloalanine & Amino acids \\
\hline D2 & D-Mannitol & Carbohydrates & D4 & L-Serine & Amino acids \\
\hline E2 & N-Acetyl-D-glucosamine & Carbohydrates & $\mathbf{E 4}$ & L-Threonine & Amino acids \\
\hline F2 & D-Glucosaminic acid & Carboxylic \& Acetic & F4 & Glycyl-L-glutamin acid & Amino acids \\
\hline G2 & Glucose-1-phosphate & Carbohydrates & $\mathbf{G 4}$ & Phenylethylamine & Amines and amides \\
\hline H2 & D,L- $\alpha$-Glycerol & Carbohydrates & $\mathbf{H 4}$ & Putrescine & Amines and amides \\
\hline
\end{tabular}

...where pi in the formula is the ratio of the absorbance of each substrate (ODi) to the sum of the absorbance for all the substrates ( $\left.\sum \mathrm{ODi}\right)$.

In addition, after the Shannon-Weiner functional diversity index $(\mathrm{H})$ and catabolic richness $(\mathrm{S})$ value were calculated, the Shannon Evenness (E) index was determined by the following formula using these values (Eq. 2):

$$
E=\frac{H}{\operatorname{InS}}
$$

\section{Statistical Data Analysis}

Each of the carbon source Ecoplate well values were normalized using the readings in control wells OD values [21]. After normalization, kinetic analysis was performed to data. Kinetic analysis is a time-dependent color change analysis and widely used. A sigmoidal curve is often obtained at the end of this type of analysis. The average well color development (AWCD) in each reading interval for all samples was calculated [22]. The following formula (Eq. 3) was used for analysis [23]:

$$
A W C D=\sum_{n=1}^{31}\left(\frac{\mathrm{ODi}}{31}\right)
$$

...where ODi is the optical density of each well normalized with control well.
AUC (Area Under the Curve) value was calculated using the following formula (Eq. 4) [24]:

$$
A U C=\sum_{n=1}^{31} \frac{A_{n}+A_{n+1}}{2 x\left(t_{n+1}-t\right)}
$$

...where $A_{n}$ and $A_{n+1}$ are the absorbance values of each well in two consecutive time intervals, and $t_{n}$ and $t_{n+1}$ refer to two consecutive times.

All these analysis results were compared to evaluate the effects of incubation time and sampling period on functional diversity.

\section{Results and Discussion}

Biological wastewater treatment plays an important and crucial role in wastewater treatment [25], and efficiency of operations depend on the activity of microorganisms [26]. The wide variety of bacteria and their role in wastewater are found in two biological treatment units: the active sludge process and anaerobic digestion units. Hence, treatment plant operators must understand the biological processes and organisms involved in wastewater treatment and ensure the presence of an adequate, active, and appropriate bacterial population in each process [27]. The growth of bacteria in wastewater treatment plants and the consequent efficiency of treatment is influenced by various nutritional and physical factors [27] and these factors must be controlled at the same time. In this study, the effects 


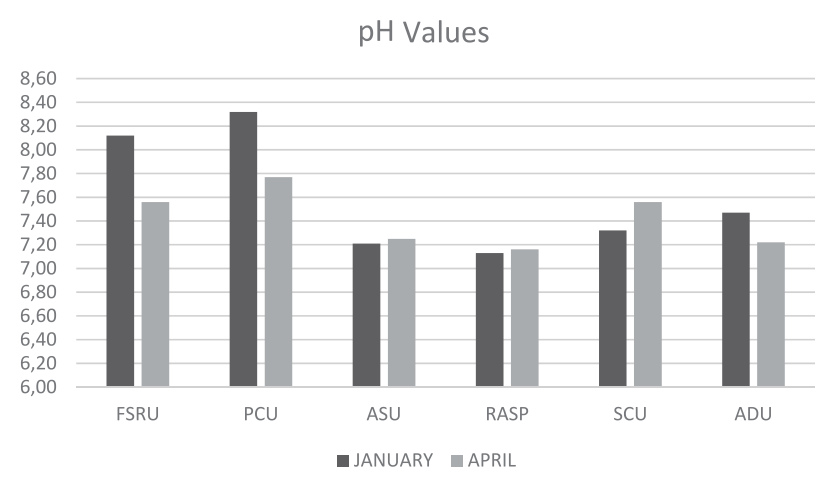

Fig. 1. The $\mathrm{pH}$ value of the different operational units in January and April samplings.

of operational parameters and microbial communities in treatment plant units were investigated. For this purpose the Biolog Ecoplate culture-based approach was selected. Biolog Ecoplates were used for diverse applications of microbial ecology and concluded that Ecoplates in detecting population changes in soil, water, wastewater, activated sludge, compost, and industrial wastes are important and practical tools [12, 20, 25, 28-34].

\section{Physico-Chemical Analysis}

$\mathrm{pH}$ and ICP measurements for wastewater samples taken at two different times from treatment plants were obtained and produced different results (Fig. 1 and Table 2). When the $\mathrm{pH}$ values of sampling units were evaluated, values ranged from 7.13 to 8.32 . January and April samplings did not yield a significant difference between $\mathrm{pH}$ values. Control of $\mathrm{pH}$ is an important parameter in determining the treatment method to be applied, in removal of turbidity, disinfection in water softening, and corrosion control [35]. In addition, the precipitation of some heavy metals and biological activity in wastewater treatment systems depend on the various $\mathrm{pH}$ values $[27,36]$. Bacteria suggest the most effective activity in the range of 6.8 to 7.2. When these values change, efficiency decreases [27]. So, we measured $\mathrm{pH}$ values to analyze changes of parameters for treatment process and microbial activities. In our results, the $\mathrm{pH}$ of all operational units were similar to other studies [24$25,37]$. Only FSRU and PCU values were higher in January. Temperature, waste type, operational conditions, or waste loads may affect these values. But for biological activity, the $\mathrm{pH}$ values of ASU and ADU were near neutral in all samplings. The neutral $\mathrm{pH}$ values were obtained from another study for anaerobic digester units that also indicated suitable conditions [38].

ICP analyses were performed to determine some of the elements in the samples. $\mathrm{Na}^{+}, \mathrm{Ca}^{2+}, \mathrm{Mg}^{2+}$, and $\mathrm{K}^{+}$ions were dominant in all samples. $\mathrm{Na}+$ was higher in January, while $\mathrm{Ca}^{2+}$ ions were higher in April. The $\mathrm{K}^{+}$ion ratio was higher in ADU in all samplings. When results were compared, dominant ion values also increased in April.

Table 2. The ICP values of the different operational units in January and April samplings.

\begin{tabular}{|c|c|c|c|c|c|c|c|c|c|c|c|}
\hline \multirow{7}{*}{ 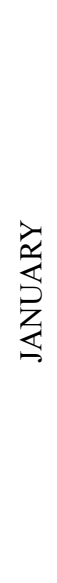 } & SAMPLES & $\mathrm{Mg}^{2+}$ & $\mathrm{Ca}^{2+}$ & $\mathrm{Na}^{+}$ & $\mathrm{K}^{+}$ & $\mathrm{Fe}^{2+}$ & $\mathrm{Zn}^{2+}$ & $\mathrm{Ni}^{2+}$ & $\mathrm{Mn}^{2+}$ & $\mathrm{Cr}^{2+}$ & $\mathrm{Al}^{3+}$ \\
\hline & FSRU & $\begin{array}{l}38.2 \\
\text { ppm }\end{array}$ & $\begin{array}{l}51.33 \\
\mathrm{ppm}\end{array}$ & $\begin{array}{c}78.61 \\
\text { ppm }\end{array}$ & $\begin{array}{c}23.86 \\
\mathrm{ppm}\end{array}$ & $\begin{array}{c}37.85 \\
\mathrm{ppb}\end{array}$ & $\begin{array}{c}26.08 \\
\text { ppb }\end{array}$ & $<$ & $\begin{array}{c}12.59 \\
\mathrm{ppb}\end{array}$ & $<$ & $<$ \\
\hline & PCU & $\begin{array}{c}49.10 \\
\mathrm{ppm}\end{array}$ & $\begin{array}{l}75.34 \\
\text { ppm }\end{array}$ & $\begin{array}{c}107.8 \\
\mathrm{ppm}\end{array}$ & $\begin{array}{c}28.43 \\
\mathrm{ppm}\end{array}$ & $\begin{array}{c}29.59 \\
\text { ppb }\end{array}$ & $\begin{array}{c}35.96 \\
\text { ppb }\end{array}$ & $<$ & $\begin{array}{c}10.02 \\
\mathrm{ppb}\end{array}$ & $\begin{array}{l}3.63 \\
\text { ppb }\end{array}$ & $<$ \\
\hline & ASU & $\begin{array}{c}46.13 \\
\text { ppm }\end{array}$ & $\begin{array}{c}61.31 \\
\text { ppm }\end{array}$ & $\begin{array}{c}88.81 \\
\text { ppm }\end{array}$ & $\begin{array}{c}31.89 \\
\text { ppm }\end{array}$ & $\begin{array}{c}42.94 \\
\mathrm{ppb}\end{array}$ & $\begin{array}{c}17.25 \\
\text { ppb }\end{array}$ & $<$ & $<$ & $<$ & $<$ \\
\hline & RASP & $\begin{array}{c}51.81 \\
\mathrm{ppm}\end{array}$ & $\begin{array}{l}55.66 \\
\mathrm{ppm}\end{array}$ & $\begin{array}{c}85.08 \\
\text { ppm }\end{array}$ & $\begin{array}{c}44.45 \\
\mathrm{ppm}\end{array}$ & $\begin{array}{c}6.572 \\
\mathrm{ppb}\end{array}$ & $\begin{array}{c}6.165 \\
\mathrm{ppb}\end{array}$ & $\begin{array}{c}11.82 \\
\mathrm{ppb}\end{array}$ & $<$ & $<$ & $<$ \\
\hline & SCU & $\begin{array}{c}38.58 \\
\mathrm{ppm}\end{array}$ & $\begin{array}{l}59.51 \\
\text { ppm }\end{array}$ & $\begin{array}{l}79.96 \\
\text { ppm }\end{array}$ & $\begin{array}{c}22.58 \\
\mathrm{ppm}\end{array}$ & $<$ & $\begin{array}{c}173.2 \\
\text { ppb }\end{array}$ & $<$ & $<$ & $<$ & $<$ \\
\hline & $\mathrm{ADU}$ & $\begin{array}{c}14.04 \\
\mathrm{pm}\end{array}$ & $\begin{array}{l}53.20 \\
\mathrm{ppm}\end{array}$ & $\begin{array}{l}74.67 \\
\mathrm{ppm}\end{array}$ & $\begin{array}{c}252.5 \\
\mathrm{ppm}\end{array}$ & $\begin{array}{c}194.6 \\
\mathrm{ppb}\end{array}$ & $\begin{array}{c}23.98 \\
\text { ppb }\end{array}$ & $\begin{array}{c}20.49 \\
\text { ppb }\end{array}$ & $\begin{array}{c}3.861 \\
\mathrm{ppb}\end{array}$ & $<$ & $<$ \\
\hline \multirow{6}{*}{$\vec{z}$} & FSRU & $\begin{array}{l}102.9 \\
\mathrm{ppm}\end{array}$ & $\begin{array}{c}179.4 \\
\text { ppm }\end{array}$ & $\begin{array}{c}107.8 \\
\mathrm{ppm}\end{array}$ & $\begin{array}{c}51.05 \\
\mathrm{ppm}\end{array}$ & $\begin{array}{c}<0.16 \\
\mathrm{ppm}\end{array}$ & $\begin{array}{c}83.24 \\
\text { ppb }\end{array}$ & $<$ & $\begin{array}{c}31.30 \\
\mathrm{ppb}\end{array}$ & $<$ & $<$ \\
\hline & PCU & $\begin{array}{c}93.27 \\
\text { ppm }\end{array}$ & $\begin{array}{c}180.6 \\
\text { ppm }\end{array}$ & $\begin{array}{c}95.34 \\
\text { ppm }\end{array}$ & $\begin{array}{c}35.24 \\
\mathrm{ppm}\end{array}$ & $\begin{array}{c}<0.16 \\
\mathrm{ppm}\end{array}$ & $\begin{array}{c}88.20 \\
\text { ppb }\end{array}$ & $<$ & $<$ & $<$ & $<$ \\
\hline & ASU & $\begin{array}{c}87.24 \\
\text { ppm }\end{array}$ & $\begin{array}{l}167.8 \\
\mathrm{ppm}\end{array}$ & $\begin{array}{c}104.2 \\
\mathrm{ppm}\end{array}$ & $\begin{array}{c}39.87 \\
\mathrm{ppm}\end{array}$ & $\begin{array}{l}<0.16 \\
\mathrm{ppm}\end{array}$ & $\begin{array}{c}161.7 \\
\text { ppb }\end{array}$ & $<$ & $<$ & $<$ & $<$ \\
\hline & RASP & $\begin{array}{c}99.24 \\
\text { ppm }\end{array}$ & $\begin{array}{l}218 \\
\mathrm{ppm}\end{array}$ & $\begin{array}{c}185.1 \\
\mathrm{ppm}\end{array}$ & $\begin{array}{c}61.67 \\
\mathrm{ppm}\end{array}$ & $\begin{array}{c}<0.16 \\
\text { ppm }\end{array}$ & $\begin{array}{c}61.50 \\
\text { ppb }\end{array}$ & $\begin{array}{c}12.12 \\
\mathrm{ppb}\end{array}$ & $<$ & $<$ & $<$ \\
\hline & SCU & $\begin{array}{c}89.05 \\
\text { ppm }\end{array}$ & $\begin{array}{c}182.2 \\
\mathrm{ppm}\end{array}$ & $\begin{array}{l}105.5 \\
\mathrm{ppm}\end{array}$ & $\begin{array}{c}38.65 \\
\mathrm{ppm}\end{array}$ & $\begin{array}{c}<0.16 \\
\mathrm{ppm}\end{array}$ & $\begin{array}{c}196.5 \\
\text { ppb }\end{array}$ & $<$ & $<$ & $<$ & $<$ \\
\hline & ADU & $\begin{array}{c}46.39 \\
\mathrm{ppm}\end{array}$ & $\begin{array}{c}196.2 \\
\mathrm{ppm}\end{array}$ & $\begin{array}{c}97.46 \\
\text { ppm }\end{array}$ & $\begin{array}{c}385.6 \\
\mathrm{ppm}\end{array}$ & $\begin{array}{c}0.302 \\
\mathrm{ppm}\end{array}$ & $\begin{array}{c}77.95 \\
\text { ppb }\end{array}$ & $\begin{array}{c}31.79 \\
\mathrm{ppb}\end{array}$ & $\begin{array}{c}10.94 \\
\mathrm{ppb}\end{array}$ & $<$ & $\begin{array}{c}27.43 \\
\text { ppb }\end{array}$ \\
\hline
\end{tabular}


Table 3. Results of statistical analysis (group statistics and Student T-test) using SPSS software.

\begin{tabular}{|c|c|c|c|c|c|c|c|c|c|c|}
\hline \multicolumn{6}{|c|}{ Group Statistics } & \multicolumn{5}{|c|}{ Levene's Test for Equality of Variances } \\
\hline & Month & $\mathrm{N}$ & Mean & Std. Deviation & $\begin{array}{l}\text { Std. Error } \\
\text { Mean }\end{array}$ & $\mathrm{F}$ & Sig. & Sig. (2-tailed) & $\begin{array}{c}\text { Mean } \\
\text { Difference }\end{array}$ & $\begin{array}{l}\text { Std. Error } \\
\text { Difference }\end{array}$ \\
\hline \multirow{2}{*}{$\mathrm{Mg}^{2+}$} & January & 6 & 39.6433 & 13.69874 & 5.59249 & .325 & .581 & .001 & -46.70500 & 10.05170 \\
\hline & April & 6 & 86.3483 & 20.45886 & 8.35229 & & & & & \\
\hline \multirow{2}{*}{$\mathrm{Ca}^{2+}$} & January & 6 & 59.3917 & 8.66367 & 3.53693 & 2.343 & .157 & .000 & -127.97500 & 7.98024 \\
\hline & April & 6 & 187.3667 & 17.52275 & 7.15363 & & & & & \\
\hline \multirow{2}{*}{$\mathrm{Na}^{+}$} & January & 6 & 85.8217 & 11.85963 & 4.84167 & 2.205 & .168 & .069 & -30.07833 & 14.79336 \\
\hline & April & 6 & 115.9000 & 34.24046 & 13.97861 & & & & & \\
\hline \multirow{2}{*}{$\mathrm{K}^{+}$} & January & 6 & 67.2850 & 91.07449 & 37.18101 & .521 & .487 & .620 & -34.72833 & 67.93488 \\
\hline & April & 6 & 102.0133 & 139.27069 & 56.85702 & & & & & \\
\hline \multirow{2}{*}{$\mathrm{Zn}^{2+}$} & January & 6 & 47.1058 & 62.55938 & 25.53976 & .024 & .880 & .086 & -64.40917 & 33.80362 \\
\hline & April & 6 & 111.5150 & 54.24419 & 22.14510 & & & & & \\
\hline
\end{tabular}

$(\mathrm{P}<0.05)$

When measured in terms of other elements, although the amount was a low rate, $\mathrm{Zn}^{2+}$ was determined. As the statistical analysis showed in Table 3 for elements, there was a significant difference (Students $t$ test, $p<0.05$ ) in $\mathrm{Mg}^{2+}$ and $\mathrm{Ca}^{2+}$ levels between January and April samples. The $\mathrm{Na}^{+}, \mathrm{K}^{+}$, and $\mathrm{Zn}^{2+}$ levels of January and April samples showed no significant difference.

Ions such as $\mathrm{Na}^{+}, \mathrm{Ca}^{2+}$, and $\mathrm{Mg}^{2+}$ are the measure of salinity. While it is normal to have a low amount of salt in the water, mixing wastewater with domestic, agricultural, and industrial waters increases salinity. In this situation, the $\mathrm{NaCI}$ concentration affects the biological treatment performance. Studies showed that the addition of $\mathrm{NaCl}$ leads to an increase in respiration rates and a certain concentration causes the decrease. Also, this ratio affects floc structure [39]. Another important parameter in wastewater analysis is the detection of trace and heavy metal contamination. Determining these elements is an important step for human and environmental health [40]. In addition, high amounts of sludge require effective treatment. Storage of this sludge causes environmental problems. Sludge includes very rich organic matter and nutrients, so it can be used biotechnologically in some areas, such as agriculture. But heavy metal contamination

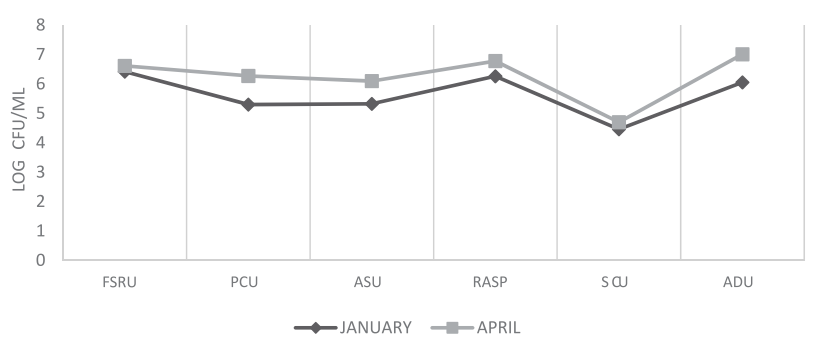

Fig. 2. Total mesophilic bacteria counts of different operational units in January and April samplings. is an undesired property. For this purpose the use of sludge and determination of quality needs rapid methods [25]. ICP analysis shows increased heavy metal contamination. This contamination affects microbial communities, diversity of substrate utilization, and catabolic functions [23]. If we compare our metal concentrations with other studies our results show that sludge quality was good and had a low amount of heavy metal contamination, and that operational treatment conditions were nearly optimal [41].

\section{Enumeration of Mesophilic Bacteria}

Total mesophilic bacteria count was calculated from different operational units as shown in Fig. 2. When the number of microorganisms in winter (January) and spring (April) were compared, enumeration results showed that in spring, the number of microorganisms is higher than in winter. In terms of FSRU and SCU operational units, the number of bacteria increased nearly two-fold, and PCU, ASU, and ADU showed a 10-fold difference in two sampling intervals. The enumeration results of operational units listed in January, in descending order, were: FSRU $>$ RASP $>$ ADU $>$ ASU $>$ PCU $>$ SCU, and for April: ADU $>$ RASP $>$ FSRU $>$ PCU $>$ ASU $>$ SCU. The reasons for these results may be seasons. In winter temperature is generally lower than in spring. Effluent loading rate may decrease in winter. The rain rate is high in the spring. This affects effuluent rate, organic load, and operational conditions. In our results, especially SCU cell density were lower than and ecoplate data were different from other units. The main reason for the SCU last step in treatment and after treatment, is that it is expected that the number of bacteria and organic rate are low. The number of living cells is important for biological treatment processes and cultural methods and can also be used to identify and enumerate pathogenic bacteria [42]. In our 
Table 4. January sampling AWCD. Shannon-Weiner functional diversity index (H), catabolic richness (S), Shannon Evenness (E) index, and area under the curve (AUC) values for 24-48-72 and 96 hours.

\begin{tabular}{|c|c|c|c|c|c|}
\hline Samples (24-hour) & \multicolumn{5}{|c|}{ Indices } \\
\hline JANUARY & AWCD & $\mathrm{H}$ & $\mathrm{E}$ & S & AUC \\
\hline FSRU & $1.605 \pm 0.062$ & $3.378 \pm 0.011$ & $0.984 \pm 0.003$ & 31 & \\
\hline PCU & $1.300 \pm 0.035$ & $3.340 \pm 0.021$ & $0.973 \pm 0.006$ & 31 & \\
\hline ASU & $1.553 \pm 0.059$ & $3.383 \pm 0.011$ & $0.985 \pm 0.003$ & 31 & \\
\hline RASP & $2.751 \pm 0.031$ & $3.432 \pm 0.001$ & 0.999 & 31 & \\
\hline $\mathrm{SCU}$ & $0.549 \pm 0.065$ & $2.799 \pm 0.094$ & $1.018 \pm 0.018$ & $15.667 \pm 1.155$ & \\
\hline $\mathrm{ADU}$ & $1.969 \pm 0.096$ & $3.400 \pm 0.001$ & $0.990 \pm 0.002$ & 31 & \\
\hline Samples (48-hour) & \multicolumn{5}{|c|}{ Indices } \\
\hline JANUARY & AWCD & $\mathrm{H}$ & $\mathrm{E}$ & $\mathrm{S}$ & AUC \\
\hline FSRU & $1.651 \pm 0.075$ & $3.399 \pm 0.005$ & $0.990 \pm 0.002$ & 31 & \\
\hline PCU & $1.334 \pm 0.201$ & $3.319 \pm 0.096$ & $0.966 \pm 0.028$ & 31 & \\
\hline $\mathrm{ASU}$ & $1.785 \pm 0.033$ & $3.405 \pm 0.003$ & $0.991 \pm 0.001$ & 31 & \\
\hline RASP & $2.680 \pm 0.077$ & $3.415 \pm 0.018$ & $0.995 \pm 0.005$ & 31 & \\
\hline $\mathrm{SCU}$ & $1.537 \pm 0.065$ & $3.358 \pm 0.015$ & $0.994 \pm 0.002$ & $29.333 \pm 577$ & \\
\hline $\mathrm{ADU}$ & $2.386 \pm 0.103$ & $3.427 \pm 0.002$ & $0.998 \pm 0.001$ & 31 & \\
\hline Samples (72-hour) & \multicolumn{5}{|c|}{ Indices } \\
\hline JANUARY & AWCD & $\mathrm{H}$ & $\mathrm{E}$ & $\mathrm{S}$ & AUC \\
\hline FSRU & $1.643 \pm 0.087$ & $3.409 \pm 0.003$ & $0.993 \pm 0.001$ & 31 & \\
\hline PCU & $1.352 \pm 0.165$ & $3.333 \pm 0.085$ & $0.971 \pm 0.025$ & 31 & \\
\hline ASU & $1.758 \pm 0.025$ & $3.395 \pm 0.002$ & $0.989 \pm 0.000$ & 31 & \\
\hline RASP & $2.705 \pm 0.093$ & $3.415 \pm 0.016$ & $0.995 \pm 0.005$ & 31 & \\
\hline $\mathrm{SCU}$ & $1.841 \pm 0.114$ & $3.406 \pm 0.008$ & $0.992 \pm 0.002$ & 31 & \\
\hline $\mathrm{ADU}$ & $2.355 \pm 0.042$ & $3.428 \pm 0.002$ & $0.998 \pm 0.001$ & 31 & \\
\hline Samples (96-hour) & \multicolumn{5}{|c|}{ Indices } \\
\hline JANUARY & AWCD & $\mathrm{H}$ & $\mathrm{E}$ & $\mathrm{S}$ & AUC \\
\hline FSRU & $1.641 \pm 0.106$ & $3.413 \pm 0.001$ & $0.994 \pm 0.000$ & 31 & 118.2568 \\
\hline PCU & $1.380 \pm 0.201$ & $3.326 \pm 0.103$ & $0.969 \pm 0.030$ & 31 & 96.62632 \\
\hline ASU & $1.791 \pm 0.078$ & $3.402 \pm 0.005$ & $0.991 \pm 0.002$ & 31 & 125.7799 \\
\hline RASP & $2.796 \pm 0.115$ & $3.418 \pm 0.012$ & $0.995 \pm 0.003$ & 31 & 197.4979 \\
\hline $\mathrm{SCU}$ & $1.881 \pm 0.141$ & $3.416 \pm 0.006$ & $0.995 \pm 0.002$ & 31 & 96.626 \\
\hline ADU & $2.330 \pm 0.034$ & $3.427 \pm 0.001$ & $0.998 \pm 0.000$ & 31 & 166.696 \\
\hline
\end{tabular}

study approximately $10^{6}-10^{7} \mathrm{cfu} \mathrm{ml}^{-1}$ mesophilic bacteria counted. In another study, a heterotrophic bacteria count revealed $10^{10} \mathrm{cfu} \mathrm{ml}^{-1}$ on TSB agar. This study indicated that for substrate utilization, cell density was important and the low number of cells required a long time for adaption to environmental conditions [38]. Our data supported this and have similar results.
Functional Community Analysis

Tables 4 and 5 indicate average well color development (AWCD), Shannon-Wiener functional diversity index $(\mathrm{H})$, catabolic richness (S), Shannon Evenness (E) index, and area under the curve (AUC) values for the January and April samples. In most of the operational units we used 
Table 5. April sampling AWCD, Shannon-Weiner functional diversity index (H), catabolic richness (S), Shannon Evenness (E) index, and area under the curve (AUC) values for 24-48-72 and 96 hours.

\begin{tabular}{|c|c|c|c|c|c|}
\hline Samples (24-hour) & \multicolumn{5}{|c|}{ Indices } \\
\hline APRİL & AWCD & $\mathrm{H}$ & $\mathrm{E}$ & $\mathrm{S}$ & AUC \\
\hline FSRU & $1.687 \pm 0.005$ & $3.366 \pm 0.007$ & $0.980 \pm 0.002$ & 31 & \\
\hline PCU & $1.457 \pm 0.235$ & $3.359 \pm 0.025$ & $0.981 \pm 0.004$ & $30.333 \pm 0.577$ & \\
\hline ASU & $1.34 \pm 0.028$ & $3.313 \pm 0.010$ & $0.965 \pm 0.003$ & 31 & \\
\hline RASP & $2.749 \pm 0.054$ & $3.423 \pm 0.003$ & $0.997 \pm 0.001$ & 31 & \\
\hline $\mathrm{SCU}$ & $0.787 \pm 0.029$ & $3.166 \pm 0.023$ & $0.958 \pm 0.018$ & $27.333 \pm 2.082$ & \\
\hline $\mathrm{ADU}$ & $2.311 \pm 0.034$ & $3.413 \pm 0.003$ & $0.994 \pm 0.001$ & 31 & \\
\hline Samples (48-hour) & \multicolumn{5}{|c|}{ Indices } \\
\hline APRILI & AWCD & $\mathrm{H}$ & E & $\mathrm{S}$ & AUC \\
\hline FSRU & $1.871 \pm 0.264$ & $3.364 \pm 0.093$ & $0.993 \pm 0.004$ & 31 & \\
\hline $\mathrm{PCU}$ & $1.746 \pm 0.197$ & $3.405 \pm 0.012$ & $0.992 \pm 0.004$ & 31 & \\
\hline ASU & $1.826 \pm 0.032$ & $3.383 \pm 0.005$ & $0.985 \pm 0.001$ & 31 & \\
\hline RASP & $2.797 \pm 0.044$ & $3.425 \pm 0.006$ & $0.997 \pm 0.002$ & 31 & \\
\hline $\mathrm{SCU}$ & $1.265 \pm 0.054$ & $3.281 \pm 0.022$ & $0.968 \pm 0.006$ & $29.666 \pm 0.577$ & \\
\hline $\mathrm{ADU}$ & $2.525 \pm 0.053$ & $3.423 \pm 0.003$ & $0.997 \pm 0.000$ & 31 & \\
\hline Samples (72-hour) & \multicolumn{5}{|c|}{ Indices } \\
\hline APRIIL & AWCD & $\mathrm{H}$ & E & $\mathrm{S}$ & AUC \\
\hline FSRU & $1.871 \pm 0.262$ & $3.368 \pm 0.099$ & $0.994 \pm 0.006$ & 31 & \\
\hline PCU & $1.746 \pm 0.192$ & $3.411 \pm 0.004$ & $0.993 \pm 0.002$ & 31 & \\
\hline ASU & $1.932 \pm 0.041$ & $3.398 \pm 0.011$ & $0.990 \pm 0.003$ & 31 & \\
\hline RASP & $2.746 \pm 0.053$ & $3.442 \pm 0.009$ & $0.996 \pm 0.003$ & 31 & \\
\hline $\mathrm{SCU}$ & $1.329 \pm 0.093$ & $3.304 \pm 0.022$ & $0.965 \pm 0.010$ & $30.667 \pm 0.577$ & \\
\hline $\mathrm{ADU}$ & $2.468 \pm 0.041$ & $3.425 \pm 0.002$ & $0.997 \pm 0.000$ & 31 & \\
\hline Samples (96-hour) & \multicolumn{5}{|c|}{ Indices } \\
\hline APRIIL & AWCD & $\mathrm{H}$ & $\mathrm{E}$ & $\mathrm{S}$ & AUC \\
\hline FSRU & $1.883 \pm 0.240$ & $3.381 \pm 0.080$ & $0.991 \pm 0.012$ & 31 & 132.6625 \\
\hline $\mathrm{PCU}$ & $1.755 \pm 0.176$ & $3.414 \pm 0.007$ & $0.994 \pm 0.002$ & 31 & 122.3605 \\
\hline ASU & $1.936 \pm 0.052$ & $3.402 \pm 0.009$ & $0.991 \pm 0.003$ & 31 & 129.5079 \\
\hline RASP & $2.696 \pm 0.036$ & $3.422 \pm 0.010$ & $0.996 \pm 0.003$ & 31 & 200.7845 \\
\hline $\mathrm{SCU}$ & $1.380 \pm 0.122$ & $3.322 \pm 0.026$ & $0.970 \pm 0.010$ & $30.667 \pm 0.577$ & 88.25484 \\
\hline $\mathrm{ADU}$ & $2.384 \pm 0.037$ & $3.425 \pm 0.002$ & $0.997 \pm 0.000$ & 31 & 179.5467 \\
\hline
\end{tabular}

31 carbon sources. This is indicated by the high diversity index values. RASP was a highly active community when $\mathrm{H}$ was evaluated, as were ADU, ASU, and FSRU. The SCU had the lowest values. The same results were obtained for AUC values. The metabolically richest two operational units in both samplings were RASP and ADU. Next, the third active units were ASU in January and FSRU was in April. Microbial community analysis was performed using the Ecoplate in this study. Substrate usage profiles and high diversity index values are the indicator of intense microbial activity and diversity [25]. Low substrate usage rates were observed in the SCU. The reason for this may be that it was the last step of the biological treatment so that organic matter rate is lower and treated water is discharged. AWCD, H, R, S, E, and AUC values describe activity and diversity of microorganisms [43]. AWCD indicates the oxidative ability of microorganisms. At the same time high values of other indices show a high 
number of oxidized $\mathrm{C}$ substrates [25]. These indices have different means for bacterial physiological diversity [13].

When we evaluated the other studies results inlet, aeration tank and outlet samples index values showed changes. Shannon diversity index values averaged between 3.2-2.3 in inlet samples, between 3.0-2.1 in aeration tank, and between 2.7-0.6 in outlet samples. Evenness values were approximately 0.9 , and AWCD values were high depending on substrate richness and Shannon diversity [37]. Our index values did not support these values, especially the Shannon diversity index, and AWCD values and substrates richness values were higher in our study. The reasons for these changes may be the presence of more organic compounds, the biodegradation potential of microbial communities, cell numbers of microorganisms, and operational effectiveness [24].

\section{Substrate Utilization in Communities}

Ecoplate contained 31 carbon sources in three replicate sets; results were measured for 96 hours. It was determined that all the carbon sources used at the end of the time period, but not used or lower usage potential carbon sources, were detected within 24, 48 and 72 hours. Carbon utilization profiles varied between the two intervals' sampling time as shown in Figs 3 and 4. Many of the samples were observed to show over OD 0.25 within 24 hours. However, differences were detected in the SCU.

The January sampling observation showed that, in PCU, 2-hydroxybenzoic acid from carboxylic and acetic acid group was not consumed within the first 48 hours and the OD values of the carbon sources increased in the $72^{\text {nd }}$ hour. When the SCU results were analyzed, $\alpha$ - ketobutyric acid from the carboxylic and acetic acid groups were used within the first 48 hours, while some carbon sources within the first 24 hours were not. Tween 80 and $\alpha$-cyclodextrin from group of polymers, i-erythritol from carbohydrate group, D-glucosaminic acid, 2-hydroxybutyric acid, 4- hydroxybenzoic acid, $\gamma$-hydroxybutyric acid, itactonic acid and D-malic acid from carboxylic and acetic acid group, in addition from the group of amino acids L-arginine, L-phenylalanine, L- threonine, glycl-Lglutamin acid, putrescine and phenylethylamine were not used. When April samples were analyzed, $\alpha$-ketobutyric acid, 2-hydroxybenzoic acid and $\gamma$-hydroxybenzoic acid from the carboxylic and acetic acid groups, $\alpha$-cyclodextrin from polymers, were not used in the SCU within first 48 hours.

Comparison of samples carbon source utilization rates (considering OD 0.8) in January showed that in PCU and FSRU, 2-hydroxybenzoic acid, $\gamma$-hydroxybutyric acid, itactonic acid, $\alpha$ - ketobutyric from carboxylic and acetic acid group, L-arginine and phenylethylamine from amino groups were consumed very slowly within the first 24 hours. In the ASU, usage of the amino acid L- arginine was slow. The use of many substrates, during the first 24 hours, was found to be slow, when the SCU data was examined. Specific substrates were used well such as glycogen from polymers, D-cellobiose, $\alpha$ - D-Lactose,
$\beta$-Methyl-D-Glucoside, D-Mannitol, N-Acetyl-D-glucose amine, Glucose-1- phosphate, D-L - $\alpha$ Glycerophosphate from carbohydrates.

In April, 2-hydroxybenzoic acid was used slowly in PCU and FSRU. In the ASU 2- hydroxybenzoic acid from carboxylic and acetic acid group and i-erythritol from carbohydrate group usage took a long incubation

a)

\section{JANUARY}

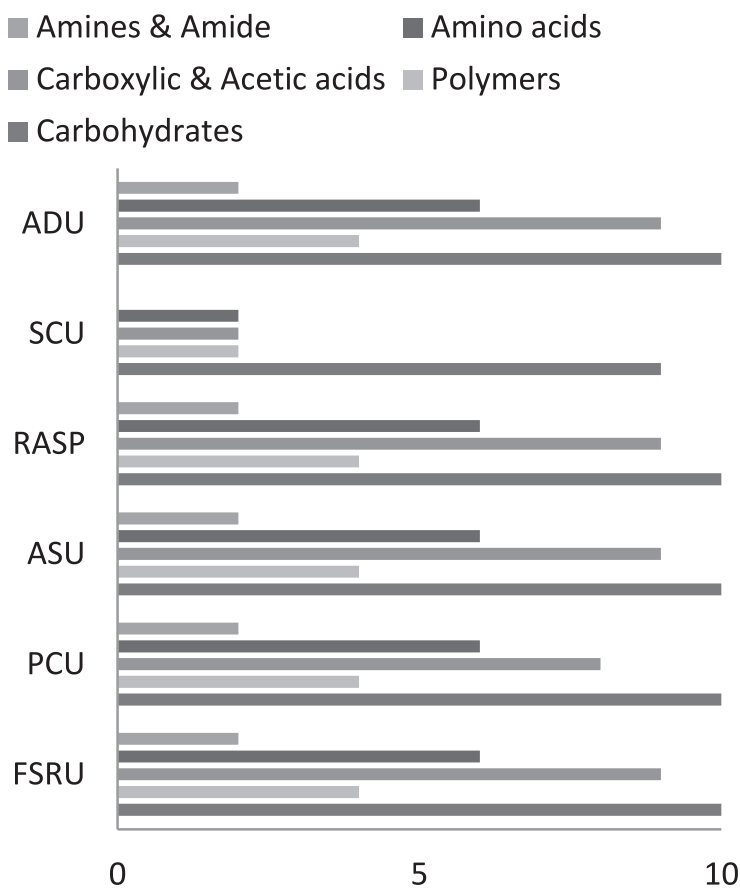

b)

\section{APRIL}

Amines \& Amide $\quad$ Amino acids
Carboxylic \& Acetic acids $\square$ Polymers
Carbohydrates

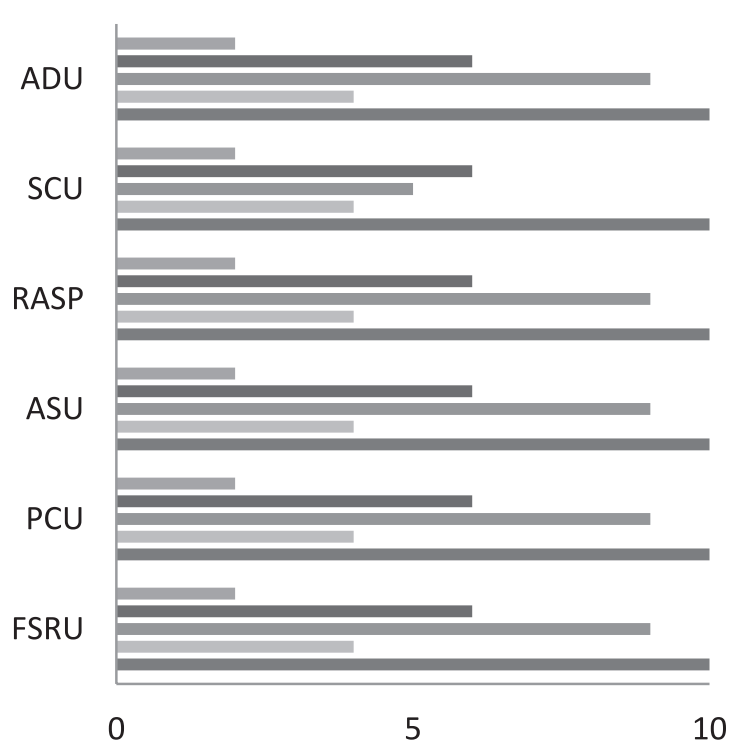

Fig. 3. a) January and b) April samplings of carbon substrate group utilization profiles for 24 hours. 
time. When the SCU was examined within the first 24 hours, only 9 of the carbon sources were well-used. These carbon sources were glycogen, D-cellobiose, $\alpha$ - D-lactose, $\beta$-methyl-D-glucoside, D-mannitol, $\mathrm{N}$-acetyl-D-glucose amine, glucose-1-phosphate from carbohydrates and D-galactyronic acid, D-galactonic acid$\gamma$-lactone from carboxylic and acetic acid group. Results for 96 hours, 2-hydroxybutyric acid, $\gamma$-hydroxybutyric acid, $\alpha$ - ketobutyric acid, D-malic acid and phenylethylamine from carboxylic and acetic acid group usage rate was slower than other carbon sources. In summary, the lowest used substrate was 2-hydroxybutyric acid, from the carboxylic acid group. The most actively used substrates were from the carbohydrate group substrates. In organic matter degradation, carboxylic and acetic acids acts as intermediates [44]. These results refer to the degradation capacity. The high catabolic capacity may indicates high number of heterotrophic bacteria. When we compared our experimental results with other studies in literature, other studies' results supported our results, 2-hydroxybutyric acid and $\gamma$-hydroxybutyric acid were not utilized as a substrate [26, 37].

a)

\section{JANUARY}

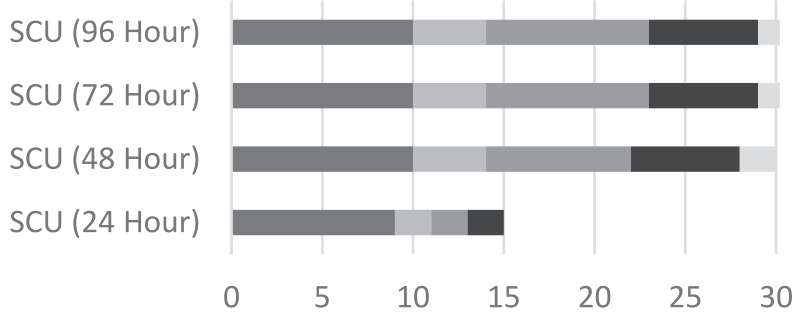

- Carbohydrates

Polymers

Carboxylic \& Acetic acids Amino acids

Amines \& Amide

b)

\section{APRIL}

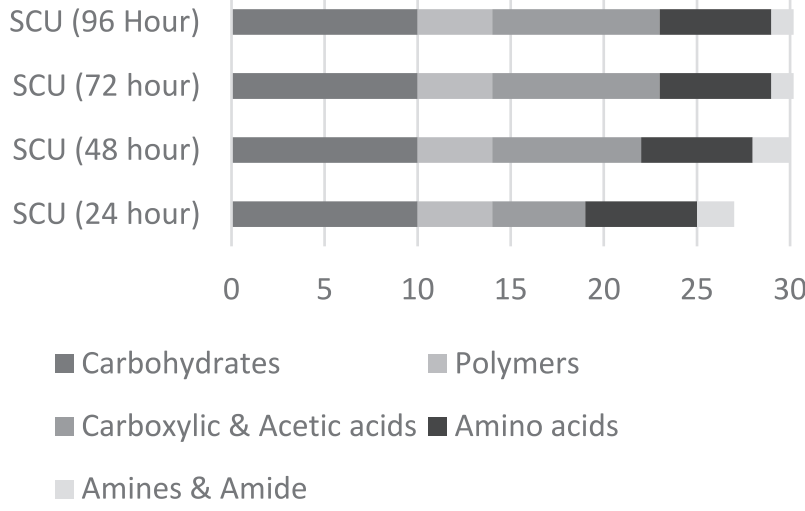

Fig. 4. a) January and b) April secondary clarifier unit (SCA) carbon substrate group utilization profiles for $24,48,72$, and 96 hours.
Kinetic Analysis and Incubation Time Effect

Kinetic analysis of the data was used to determine microbial community differences [19]. The highest AWCD values were determined for RASP and ADU, and the lowest values were determined for the SCU samples. AWCD values for January, in descending order, were listed as RASP $>$ ADU $>$ FSRU $>$ ASU $>$ PCU $>$ SCU. The lowest AWCD value was $0.549 \pm 0.065$ with SCU. However, these values varied depending on the incubation time. AWCD graphics, depending on the incubation time, were analyzed in Fig. 5. When these graphs and diversity indices were examined, differences were observed. Measurements for 96 hours showed that the PCU and SCU' AWCD values increased. In other units, AWCD values increased up to 48 hours after remaining constant.

When results were evaluated for the April sampling, again $\mathrm{RASP}>\mathrm{ADU}>\mathrm{FSRU}>\mathrm{ASU}>\mathrm{PCU}>\mathrm{SCU}$. ASU and SCU' AWCD values varied depending on the time of incubation.
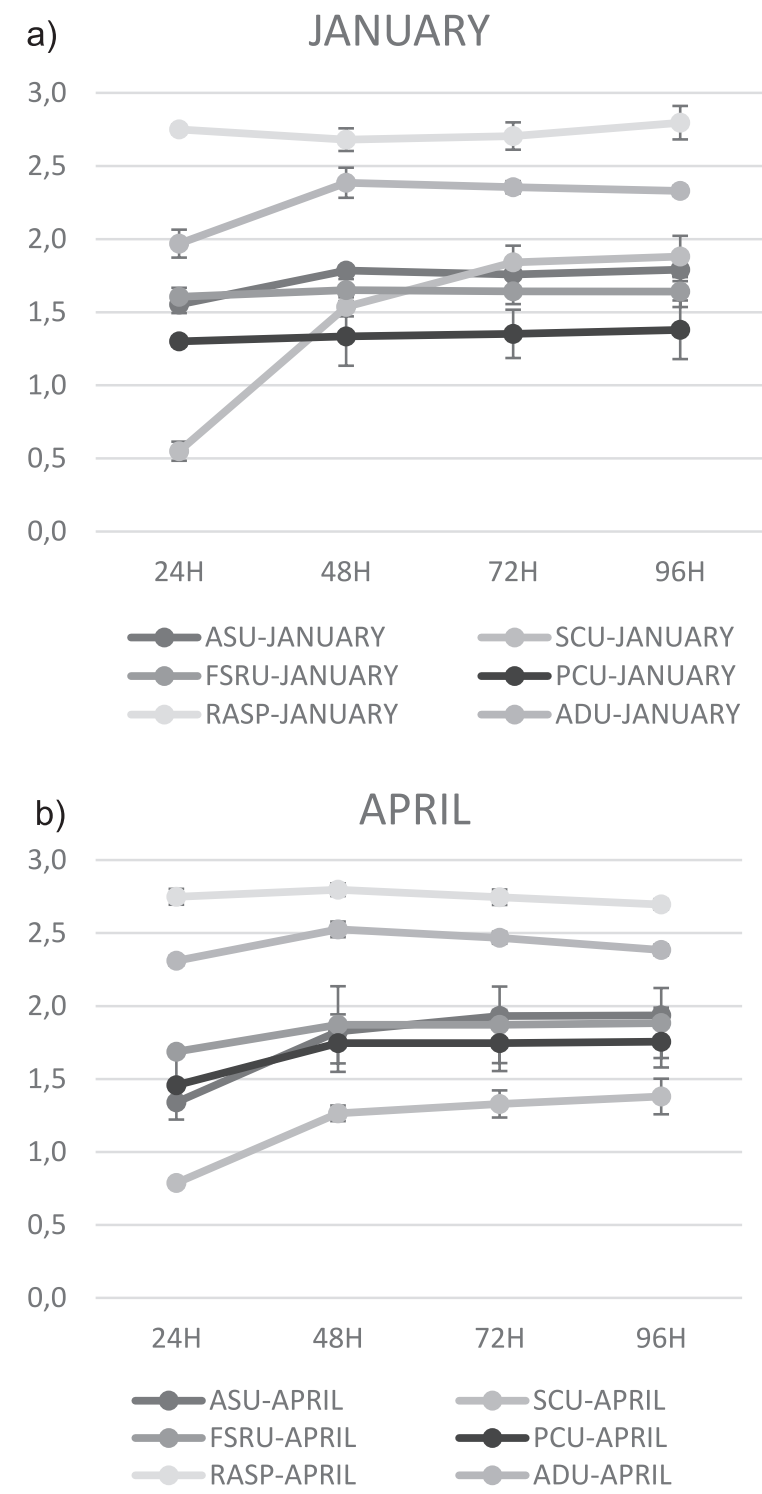

Fig. 5. a) January and b) April sampling AWCD graphics. 
When AWCD data from January was compared with the April samplings, within the first 24 hours FSRU, PCU, SCU, and ADU values were high in April, ASU of AWCD value was high in January, and the RASP values were the same in both samples. The ASU was high in April and SCU was high in January for other incubation times.

In addition, AWCD graphics showed development phases of the samples, such as lag phase or exponential phase. The lag phase may show the adaptation of the community to substrate degradation. The lag phase may also be an indicator of the low number of microorganisms. In this phase, microorganisms synthesize new enzymes for organic matter. Communities can increase population numbers in this process. SCU entered the exponential phase in January, and RASP entered the exponential phase within 24 hours. The ADU also entered within 48 hours. In April, SCU was the last one and after ASU, PCU, and FSRU were listed. RASP and ADU were entered within 48 hours. In these units, rapid response can be correlated with high population rates. This can also be determined by increases in values.

In summary, Biolog Ecoplates used microbial community analysis, with a community level physiological profiles approach. This method is used for evaluating metabolic profiles for dairy sewage sludge [25, 45], composting process [46], constructed wetlands [47], soil [48], wastewater treatment system [25], and activated sludge [26]. This technique is practical, effective, and easy. However, there are some disadvantages in using this technique. Because of the microbial diversity, different nutrient demands and species interactions affect substrate utilization on a plate. Fast growing bacteria utilize carbon sources; also, in low-density populations, slow-growing bacteria are not detected with this technique. In addition, some microorganisms do not utilize substrates on a plate, and some of them are not able to reduce tetrazolium dye. So, this technique investigates functional metabolic activity for only part of a community [29]. Despite these disadvantages, studies support the idea that this technique supplies a quick view of the wastewater treatment process. Our study results indicated that the utilization of 31 substrates and the high diversity values showed highly active microbial communities. The lowest-level substrate utilization was observed for SCU. The reason for this result may be the low microbial population after treatment. Utilization profiles were analyzed for specific groups of substrates for 24, 48, 72, and 96 hours. The least utilized substrate was 2-hydroxy benzoic acid from carboxylic and acetic acid. Highly utilized substrates belonged to carbohydrates. Kinetic analysis was also performed. SCU required a long lag phase. Higher AWCD values belonged to RASP and ADU. The reason for the high values was the rapid response of the high population level. Also, we monitored microbial communities of wastewater treatment units for two different time intervals. We selected these two intervals seasonally. The reason was the investigation of temperature changes, operational differences, and waste loading effects on bacteria. Temperature changes may affect dissolved oxygen capacity and efficiency of nitrification and bacterial interactions [49]. Optimum temperatures for bacterial activity are in the range $25-35^{\circ} \mathrm{C}$ [50]. When temperature decreases, a number of important changes occur in cell physiology, such as a decrease in membrane fluidity and stabilization of the secondary structures of nucleic acids. Upon temperature downshift, it becomes a temporary stop in cell growth for 3 to $6 \mathrm{~h}$ [51]. If we associate it with our work, samples were taken in winter and spring, so temperature differences in two season and this parameter may affect wastewater treatment plants' microbial composition and effluent loading, and then in parallel our results are affected. Results showed that there was no significant change in diversity indices, but total mesophilic bacteria number and dominant ion values were higher in spring (April) sampling.

\section{Conclusions}

In this work, Biolog-Ecoplates were used to evaluate the microbial community function of different operational units from wastewater treatment plants. These wastewater treatment systems are contaminated with hundreds of compounds, and the pollution load of the system depends on many variables, such as hour, season, waste type, population density, operation type of the operator, and operational conditions. Certain parameters need to be kept constant to provide an efficient biological treatment. The most critical parameter is the variety and number of microorganisms. For this purpose, Biolog Ecoplates are useful for determining microbial communities and factors affecting communities and most utilized substrates, and are also cheap, practical, and fast. This technique is a good indicator of understanding ecosystems, in terms of having detailed analysis about communities in wastewater treatment systems, and if necessary, it is important to determine the amount of inoculum and microorganism diversity in order to achieve biological treatment efficiency. This technique is crucial and effective for determining physiological properties of microbial communities and changes in ecosystems. Our study was preliminary in wastewater bacteria monitoring. In this study we tested results with two seasonal samples. In future work method efficieny can be evaluate with daily and hourly samples. Also, alternative methods can be used for detailed investigations of physiological profiles of microbial communities, such as the deep-well microtiter plates method and microplates with the use of fluorometric detection of oxygen consumption as a measure of microbial activity.

\section{Acknowledgements}

This work was supported by Anadolu University Research Foundation Grant No. 1504F169. The authors are grateful to Ozgur Poyraz and Suat Sezen for their help and support. 


\section{References}

1. MCMARTHY J.J., CANZIANI O.F., LEARY N.A., DOKKEN D.J., WHITE K.S. Climate Change 2001: Impacts, Adaptation, and Vulnerability: Contribution of Working Group II to the Third Assessment Report of the Intergovernmental Panel on Climate Change, Cambridge University Press, New York. 2001.

2. FAO, Food and Agriculture Organization of the United Nations, http://www.fao.org/nr/water/index.html. 2008.

3. NIELSEN P.H., KRAGELUND C., SEVIOUR R.J., NIELSEN J.L. Identity and ecophysiology of filamentous bacteria in activated sludge. FEMS Microbial. Rev. 33 (6), 969, 2009

4. NIELSEN P.H., SAUNDERS A.M., HANSEN A.A., LARSEN P., NIELSEN J.L. Microbial communities involved in enhanced biological phosphorus removal from wastewatera model system in environmental biotechnology. Curr. Opin. Biotechnol. 23 (3), 452, 2012.

5. SCHMIDT I., SLIEKERS O., SCHMID M., BOCK E., FUERST J., KUENEN J.G., JETTEN M.S.M., STROUS M. New concepts of microbial treatment processes for the nitrogen removal in wastewater. FEMS Microbial. Rev. 27 (4), 481, 2003.

6. YUAN Z., BLACKALL L.L. Sludge population optimisation: a new dimension for the control of biological wastewater treatment systems. Water Res. 6 (2), 482, 2002.

7. CURTIS T.P., SLOAN W.T. Towards the design of diversity: stochastic models for community assembly in wastewater treatment plants. Water Sci. Technol. 54 (1), 227, 2006.

8. MCMAHON K.D., MARTIN H.G., HUGENHOLTZ P. Integrating ecology into biotechnology. Curr. Opin. Biotechnol. 18 (3), 287, 2007.

9. NIELSEN P.H., MIELCZAREK A.T., KRAGELUND C., NIELSEN J.L., SAUNDERS A. M., KONG Y., HANSEN A.A., VOLLERTSEN J. A conceptual ecosystem model of microbial communities in enhanced biological phosphorus removal plants. Water Res. 44 (17), 5070, 2010.

10. BOCHNER B.R., GADZINSKI P., PANOMITROS E. Phenotype MicroArrays for high-throughput phenotypic testing and assay of gene function. Genome Res. 11, 1246, 2001. pmid: 11435407 doi: $10.1101 /$ gr. 186501

11. BRADLEY R.L., SHIPLEY B., BEAULIEU C. Refining numerical approaches for analyzing soil microbial community catabolic profiles based on carbon source utilization patterns. Soil Biol. Biochem. 38, 629, 2006. doi: 10.1016/j.soilbio.2005.07.002

12. GARLAND J., MILLS A. Classification and characterization of heterotrophic microbial communities on the basis of patterns of community-level sole-carbon-source utilization. Appl. Environ. Microbiol. 57, 2351, 1991. pmid:16348543

13. KENAROVA A,, RADEVA G., TRAYKOV I., BOTEVA S. Community level physiological profiles of bacterial communities inhabiting uranium mining impacted sites. Ecotoxicol. Environ. Saf. 100, 226, 2014. doi: 10.1016/j. ecoenv.2013.11.012

14. KIRK J.L., BEAUDETTE L.A., HART M., MOUTOGLIS P., KLIRONOMOS J.N., LEE H., TREVORS, J. T., Methods of studying soil microbial diversity. J. Microbiol. Methods. 58 (2), 169, 2004. pmid: 15234515

15. PRESTON-MAFHAM J., BODDY L., RANDERSON P.F. Analysis of microbial community functional diversity using sole-carbon-source utilization profiles-a critique. FEMS Microbiol. Ecol. 42, 1, 2002. doi: 10.1111/j.1574-6941.2002. tb00990.x. pmid:19709261
16. STEFANIS C., ALEXOPOULOS A., VOIDAROU C., VAVIAS S., BEZIRTZOGLOU E. Principle methods for isolation and identification of soil microbial communities. Folia Microbiol. 58, 61, 2013. doi: 10.1007/s12223-0120179-5

17. WIDMER F., FLIEBBACH A., LACZKO E., SCHULZEAURICH J., ZEYER J. Assessing soil biological characteristics: a comparison of bulk soil community DNAPLFA-, and BiologTM-analyses. Soil Biol. Biochem. 33, 1029, 2001. doi: 10.1016/s0038-0717(01)00006-2

18. REASONER D.J., GELDREICH E.E. A new medium for the enumeration and subculture of bacteria from potable water. Appl. Environ. Microbiol. 49 (1), 1, 1985.

19. ZAK J.C., WILLIG M.R., MOORHEAD D.L., WILDMAN H.G. Functional diversity of microbial communities: a quantitative approach. Soil Biol. Biochem. 26 (9), 1101, 1994.

20. WEBER K.P., LEGGE R.L. One-dimensional metric for tracking bacterial community divergence using sole carbon source utilization patterns. J. Microbiol. Methods. 79 (1), 55, 2009.

21. CLASSEN A.T., BOYLE S.I., HASKINS K.E., OVERBY S.T., HART S.C. Community-level physiological profiles of bacteria and fungi: plate type and incubation temperature influences on contrasting soils. FEMS Microbiol. Ecol. 44, 319, 2003. doi:10.1016/S0168-6496(03)00068-0. PMID:19719613.

22. GARLAND J.L., MILLS A.L., YOUNG J.S. Relative effectiveness of kinetic analysis vs single point readings for classifying environmental samples based on communitylevel physiological profiles (CLPP). Soil Biol. Biochem. 33, 1059, 2001. doi:10.1016/S0038-0717(01)00011-6. PMID:12194184.

23. GOMEZ E., GARLAND J., CONTİ M. Reproducibility in the response of soil bacterial community-level physiological profiles from a land use intensification gradient. Appl. Soil Ecol. 26, 21, 2006.

24. JAŁOWIECKI Ł., CHOJNIAK J.M., DORGELOH E., HEGEDUSOVA B., EJHED H., MAGNÉR J., PŁAZA G.A. Microbial Community Profiles in Wastewaters from Onsite Wastewater Treatment Systems Technology. PloS one, 11 (1), e0147725, 2016.

25. GRYTA A., FRAC M., OSZUST K. The application of the Biolog EcoPlate approach in ecotoxicological evaluation of dairy sewage sludge. Appl. Biochem. Biotechnol. 174 (4), 1434,2014

26. MICHALSKA J., WOJCIESZYŃSKA D., GREŃ I. Investigation of functional diversity and activated sludge condition using Biolog $®$ system. ACEE. 9 (1), 119 , 2016.

27. GERARDI M.H. Wastewater bacteria (Vol. 5). John Wiley \& Sons., 2006.

28. PAUL D., PANDEY G., MEIERR C., VAN DER MEER J.R., JAIN R.K. Bacterial community structure of a pesticidecontaminated site and assessment of changes induced in community structure during bioremediation. FEMS Microbiol. Ecol. 57, 116, 2006.

29. STEFANOWICZ A. The Biolog plates technique as a tool in ecological studies of microbial communities. Pol. J. Envıron. Stud. 15 (5), 669, 2006.

30. AL-MUTAIRI N.Z. Variable distributional characteristics of substrate utilization patterns in activated sludge plants in Kuwait. Bioresource Technol. 100, 1524, 2009

31. SALA M.M., ARRIETA J.M., BORAS J.A., DUARTE C.M., VAQUE D. The impact of ice melting on bacterioplankton in the Arctic Ocean. Polar Biol. 33, 1683, 2010. 
32. GARCIA S.N., CLUBBS R.L., STANLEY J.K., SCHEFFE B., YELDERMAN Jr J.C., BROOKS B.W. Comparative analysis of effluent water quality from a municipal treatment plant and two on-site wastewater treatment systems. Chemosphere 92, 38, 2013

33. MORETTI G., MATTEUCCI F., ERCOLE C., VEGLIÒ F., DEL GALLO M. Microbial community distribution and genetic analysis in a sludge active treatment for a complex industrial wastewater: a study using microbiological and molecular analysis and principal component analysis. Ann. Microbiol. 66 (1), 397, 2016.

34. CHOJNIAK J., JAŁOWIECKI Ł., DORGELOH E., HEGEDUSOVA B., EJHED H., MAGNÉR J., PŁAZA G. Application of the BIOLOG system for characterization of Serratia marcescens ss marcescens isolated from onsite wastewater technology (OSWT). Acta Biochim. Pol. 62 (4), 799, 2015.

35. MANDAL H. Influence of wastewater $\mathrm{pH}$ on turbidity. J. Environ. Res. Develop. 7 (2), 105, 2011.

36. ALWAN G.M. pH-control Problems of wastewater treatment plants. Al-Khwarizmi Engineering Journal, 4 (2), 37, 2008.

37. ZAVERI P., MUNSHI N., VAIDYA A., JHA S., KUMAR G. N. Functional microbial diversity dynamics in common effluent treatment plants of South Gujarat and hydrocarbon degradation. Can. J. Microbiol. 61 (6), 389, 2015.

38. CARDINALI-REZENDE J., MORAES A. M., COLTURATO L. F., CARNEIRO E. V., MARRIEL I. E., CHARTONE-SOUZA E., NASCIMENTO A. M. Phylogenetic and physiological characterization of organic waste-degrading bacterial communities. World J. Microbiol. Biotechnol. 27 (2), 245,2011.

39. WANG J.L., ZHAN X.M., FENG Y.C., QIAN Y. Effect of salinity variations on the performance of activated sludge system. Biomed. Environ. Sci. 18 (1), 5, 2005.

40. BAYSAL A., OZBEK N., AKMAN S. Determination of trace metals in waste water and their removal processes. INTECH Open Access Publisher, 2013.

41. CECCHINI G., CIRELLO P., ERAMO B. Partitioning dynamics and fate of metals in an urban wastewater treatment plant. Environ. Eng. Manag. J. 14 (7), 1511, 2015
42. EL-LATHY A.M., EL-TAWEEL G.E., EL-SONOSY M.W., SAMHAN F. A., MOUSSA T. A. Determination of pathogenic bacteria in wastewater using conventional and PCR techniques. Environ Biotechnol. 5, 73, 2009.

43. KAPANEN A., VIKMAN M., RAJASARKKA J., VIRTA M., ITAVAARA M. Biotests for environmental quality assessment of composted sewage sludge. Waste Manage. 33, 1451, 2013.

44. LI J., YU S. Changes in the structure and diversity of bacterial communities during the process of adaptation to organic wastewater. Can. J. Microbiol. 56, 352, 2010. doi: 10.1139/ w10-009 PMID: 20453903

45. FRĄC M., OSZUST K., LIPIEC J. Community level physiological profiles (CLPP), characterization and microbial activity of soil amended with dairy sewage sludge. Sensors, 12 (3), 3253-3268, 2012.

46. ALBRECHT R., PÉRİSSOL C., RUAUDEL F., LE PETIT J., TERROM G. Functional changes in culturable microbial communities during a co-composting process: Carbon source utilization and co-metabolism. Waste Manage., 30 (5), 764, 2010.

47. CHAZARENC F., BRISSON J., MERLIN G. Seasonal and spatial changes of microorganism communities in constructed wetlands: a community level physiological profiling analysis. International Journal of Chemical Engineering, 2010.

48. LIU W., PAN N., CHEN W., JIAO W.,WANG M. Effect of veterinary oxytetracycline on functional diversity of soil microbial community. Plant, Soil and Environ. 58 (7), 295, 2012.

49. WANG P., YU Z., ZHAO J., ZHANG H. Seasonal Changes in Bacterial Communities Cause Foaming in a Wastewater Treatment Plant. Microbial Ecol. 71 (3), 660, 2016.

50. VON SPERLING M. (Ed.). Activated sludge and aerobic biofilm reactors (Vol. 5). IWA publishing. 2007

51. PHADTARE S. Recent developments in bacterial coldshock response. Curr. Issues Mol. Biol. 6 (2), 125, 2004. 